\title{
EKSTRAKSI DATA PRODUK E-MARKETPLACE SEBAGAI STRATEGI PENGOLAHAN SEGMENTASI PASAR MENGGUNAKAN WEB CRAWLER
}

\author{
${ }^{1}$ Ade Surahman, ${ }^{2}$ A. Ferico Octaviansyah, ${ }^{3}$ Dedi Darwis \\ ${ }^{123}$ Teknik Komputer, Fakultas Teknik dan Ilmu Komputer, Universitas Teknokrat Indonesia, \\ Jl. ZA. Pagar Alam No.9 -11, Labuhan Ratu, Kec. Kedaton, Kota Bandar Lampung, Lampung 35132 \\ Email: adesurahman@teknokrat.ac.id,fericopasribu@teknokrat.ac.id, darwisdedi@teknokrat.ac.id
}

(Diterima: 29 Agustus 2019, direvisi: 18 November 2019, disetujui: 23 November 2019)

\begin{abstract}
ABSTRCT
Market Situation is something that will provide valuable benefits to increase the productivity of selling a product both conventionally and online, Indonesian e-commerce map data in the second quarter shows that the increase in sales of goods and services online is increasing, it was seen from 3 (three) major e-marketplaces namely Tokopedia, Shopee, and Bukalapak, then e-commerce activities in Indonesia in January 2019 for purchasing products or service online by 86\%, it means that $86 \%$ of activities will buy products and services which located in Indonesian e-commerce. This situation creates fierce competition for sellers or business people or entrepreneurs who are just starting their business. One way for sellers to get a primacy in this competition is to apply segmentation to the products that they will sell in the online shop, but the data from a study by the association revealed that if a product stays online for a long time (more than 550 days) then $78 \%$ is very likely not to be purchased, the product placement activity in the online shop must be segmented appropriately, this research provided an effort to apply data extraction technology with web crawlers to present the segmentation, and the results of prototype testing to 9 entrepreneurs, 210 students who will start an online business, and 19 private employees which produce web crawler technology testing to help product segmentation with the result of successful was $79 \%$ with the Good category in laying online product was segmented.
\end{abstract}

Keywords : E-Marketplace, Market Segmentation, Data Extraction, Web Crawler

\begin{abstract}
ABSTRAK
Keadaan Pasar adalah suatu hal yang akan memberikan manfaat yang berharga untuk meningkatkan produktivitas penjualan suatu produk baik secara konvensional maupun secara online, data peta $e$ commerce indonesia pada kuartal ke 2 (dua) meperlihatkan bahwa peningkatan penjualan barang dan jasa secara online meningkat, dilihat dari 3 (tiga) besar e-marketplace yaitu tokopedia, shopee dan bukalapak, kemudian di sertai aktivitas e-commerce di indonesia pada januari 2019 untuk pembelian produk atau jasa online sebesar $86 \%$, artinya aktivitas sebesar $86 \%$ akan membeli produk dan jasa yang berada di e-commerce indonesia. Keadaan ini menimbulkan persaingan ketat untuk para penjual atau pebisnis maupun penggiat wirausaha yang baru memulai usahanya, salah satu cara agar penjual mendapatkan keunggulan dalam bersaing ini adalah dengan menerapkan segmentasi pada produk yang akan mereka jual di online shop, akan tetapi data dari sebuah penelitian oleh asosiasi yang mengungkapkan bahwa jika sebuah produk tetap online untuk waktu lama (lebih dari 550 hari) maka $78 \%$ sangat mungkin tidak akan dibeli, seharusnya aktivitas peletakan produk di online shop harus tersegmentasi secara tepat, peneliti ini memberikan upaya penerapan teknologi ekstraksi data dengan web crawler untuk menyajikan segmentasi tersebut, dan hasil pengujian prototipe kepada 9 wirausaha , 210 mahasiswa yang akan memulai usaha online, dan 19 pegawai swasta menghasilkan pengujian teknologi web crawler untuk membantu segmentasi produk dengan hasil kesuksesan informasi segmentasi sebesar $79 \%$ dengan kategori Baik untuk digunakan dalam peletakan produk online yang tersegmentasi.
\end{abstract}

Kata Kunci: E-Marketplace, Segmentasi Pasar, Ekstraksi Data, Web Crawler 


\section{PENDAHULUAN}

E-marketplace adalah sistem informasi yang melakukan kegiatan bertukar barang, layanan, uang atau informasi antara pembeli dengan penjualan secara online [1]. Data kuartal ke 2 pada juli 2019 memperlihatkan bahwa indikator monthly active user (MAU) menjadi tolak ukur peta e-commerce Indonesia. Dilihat dari gambar 1 peta e-commerce indonesia memperlihatkan 3 (tiga) besar $e$ marketplace masing - masing Tokopedia sebesar 140 juta, Shopee sebesar 90 juta dan Bukalapak sebesar 89 juta untuk monthly active user (MAU) [2].

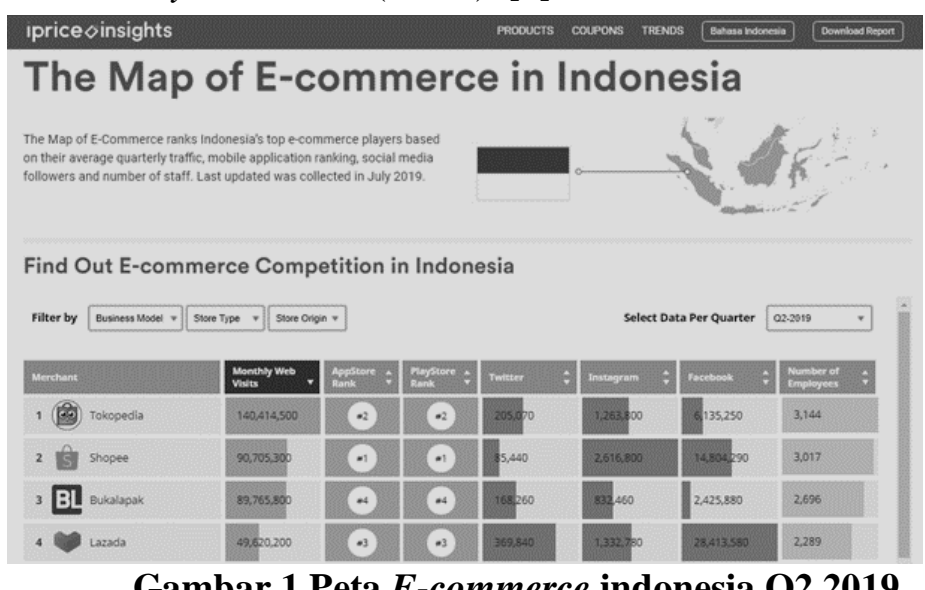

Melihat data yang ditampilkan bahwa masyarakat indonesia mulai melakukan perubahan kegiatan jual beli secara konvensional menjadi online shop, Dan dilihat dari gambar 2 pembelian produk atau jasa secara online untuk indonesia mencapai $86 \%$ perbulannya [3].

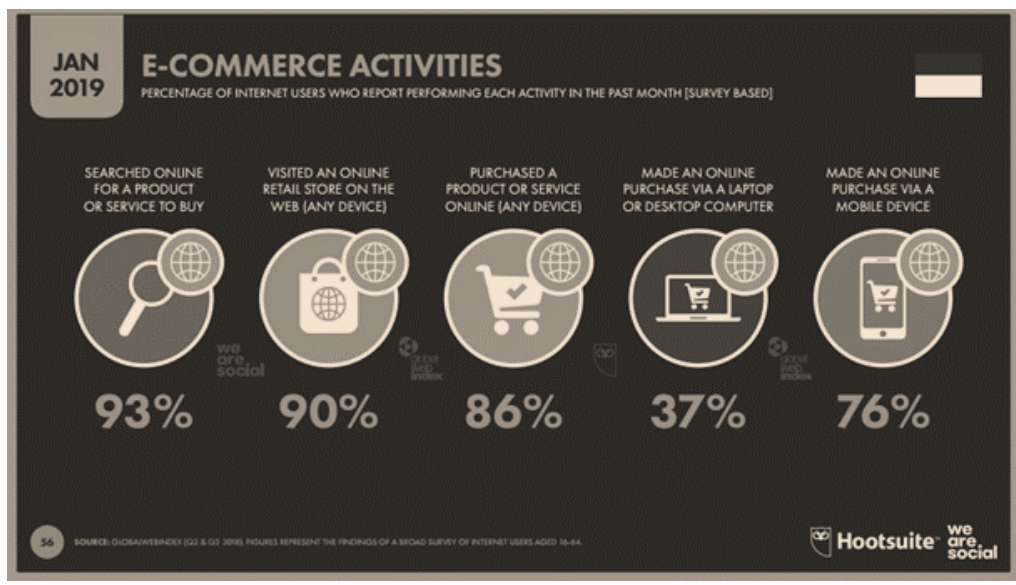

Gambar 2 E-commerce activities jan 2019

Dari kumpulan data tersebut memperlihatkan bahwa adanya kebutuhan strategi dari para pebisnis dalam melakukan penjualan di e-marketplace, karena startegi dibutuhkan untuk memenuhi kebutuhan pelanggan e-marketplace yang banyak pengujungnya, salah satunya strategi pengolahan segmentasi pasar yang dapat mengelompokan konsumen kedalam segmen konsumen secara alami maupun diciptakan secara artifisial yang memiliki preferensi atau karakteristik produk yang serupa [4], dimana segmentasi pasar memiliki keuntungan diantaranya perusahaan memiliki fokus dalam penjualannya, meningkatkan keunggulan persaingan bisnis, dapat memperluas proses maupun jangkaun penjualan, kepercayaan pelanggan terhadap pebisnis baik jasa maupun produk, memiliki komunikasi terhadap promosi produk yang dinilai oleh pelanggan, dan segmentasi dapat meningkatkan keunggulan dan meningkatkan kekuatan merk.

Segmentasi yang akan dilakukan dengan cara ekstraksi data produk e-marketplace dengan menggunakan teknologi web crawler. Web Crawler adalah sebuah program atau code otomatis yang dapat mengunjungi dan mencari informasi yang sesuai dengan kata kunci dalam sebuah website [5],

Surahman, Penulis, Judul Artikel Ekstraksi Data Produk E-Marketplace Sebagai Strategi Pengolahan Segmentasi Pasar Menggunakan Web Crawler 
teknologi web crawler yang dilakukan dengan melakukan modifikasi taq yang terdapat pada mesin simple php dom. Teknologi web crawler akan menghasilkan visualisasi keadaan produk $e$ marketplace seperti jumlah produk, nama produk, harga, dan deskripsi produk, data tersebut digunakan sebagai perbandingan untuk para pebisnis untuk panduan meletakan produk ke $e$ marketplace.

\section{TINJAUAN PUSTAKA}

\subsection{Penelitian Terdahulu}

Penelitian dilakukan dengan cara melakukan studi literatur terlebih dahulu diantaranya pada penelitian Irawan menjelaskan tentang penggunaan web crawler untuk mengambil data -data Google Playstore yang nantinya data tersebut dibuatkan web service agar dapat diakses dengan cara cross platform [6]. Penelitian Akbar dkk menjelaskan tentang penggunaan Document Object Model (DOM) untuk dilakukan ekstraksi halaman web dengan metode penelurusan Dept Fist Search (DFS) dan hasilnya aplikasi yang dibuat dapat melakukan ekstraksi data [7]. Penelitian Negara dkk menjelaskan tentang data ekstraksi twitter untuk mengambil data lokasi awal kemunculan terhadap sebuah isu di media sosial proses yang dilakukan pertama dengan melakukan penarikan data (crawling), penyimpanan, analisis dan visualisai, dan hasil penelitian bersifat exploratory sebagai upaya sumbangsih pengembangan teknologi ekstraksi data twitter geospasial [8]. Penelitian Akbar dan Wibowo menjelaskan teknik ekstraksi tabel html berupa column-row wise untuk di inputkan kedalam sebuah database dan memastikan ketertarikan antara dua atribut dan data dalam tabel tersebut tidak hilang, hasilnya penelitian memperlihatkan bahwa penggunaan algoritma usulan masih memiliki kompleksitas yang tinggi [9]. Penelitian Sasongko menjelaskan tentak penggunaan ekstraksi halaman web memberikan keuntungan dalam hal penggunaannya, penelitian ini melakukan ekstraksi halaman untuk diterapkan pada aplikasi mobile infokampus dan memperlihatkan bahwa ektraksi halaman web dalam konsumsi bandwith rata-rata per halaman sebesar $16.68 \mathrm{~kb}$ atau 91,54\% kurang dari akses melalui browser, tetapi proses per halaman rata -rata 1,75 detik artinya lebih Panjang dari brwoses sebesar $117,68 \%[10]$.

\subsection{Segmentasi Pasar}

Segmentasi pasar adalah proses membagi pelanggan, atau pelanggan potensial, di pasar menjadi kelompok-kelompok yang berbeda, atau segmen. Berikut ini pendekatan dalam segmentasi pasar [11]. 1. Produk dan Jasa

Segmentasi pasar dalam kategori produk atau jasa yang ditawarkan, atau jenis teknologi, yaitu di sebagian besar pasar terdapat berbagai jenis pelanggan yang membeli atau menggunakan produk atau jasa yang sama.

\section{Demografi}

Kategori dalam segmentasi demografi adalah jenis kelamin, umur, sosial-ekonomi (individu kelompok yang klasifikasi menurut tingkat pendapatan mereka atau pekerjaan) bila digunakan untuk menentukan segmen yaitu dengan implikasi dan klaim.

\section{Geographics}

Segmentasi pasar berdasarkan wilayah geografis yaitu menganggap bahwa setiap orang di daerah yang telah ditentukan dapat diharapkan untuk bereaksi terhadap penawaran tertentu dengan cara yang persis sama. Segmentasi ini membagi pasar menjadi unit-unit geografi yang berbeda, seperti negara, propinsi, kabupaten, kota, wilayah, daerah atau kawasan.

4. Psychographics

Segmentasi ini berhubungan dengan status sosial (pemimpin masyarakat, pendidik), gaya hidup (modern, tradisional, boros, hemat, mewah), kepribadian misalnya penggemar, pecandu atau pemerhati produk tertentu yang akan menghasilkan segmentasi pasar yang sesuai dengan kebutuhan.

\subsection{Model DeLone and McLean}

Pengukuran Kesuksesan sistem informasi telah banyak di teliti dan model DeLone dan McLean yang menyebutkan bahwa information quality, system quality dan service quality 
akan berpengaruh positif pada use dan user satisfaction dan selanjutnya akan berpengaruh positif pada net benefit atau hasil akhir [12] [13].

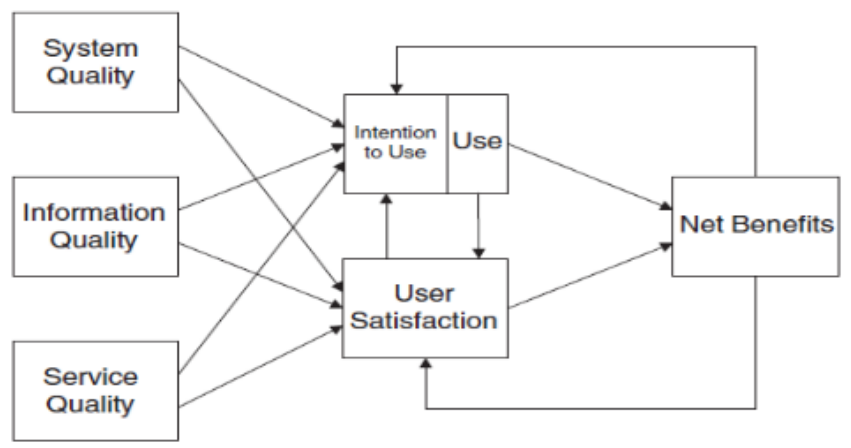

Gambar 3 Model DeLone and McLean

Model ini dapat dilakukan untuk mengukur kesuksesan sistem informasi dari sebuah sistem informasi yang dihasilkan seperti yang dilakukan oleh penelitian terdahulu [14] [15] [16], model ini akan dipadukan dengan kuesioner dan hasil dari kuesioner akan dibandingkan dengan kriteria tanggapan responden. Dimana pengujian prototipe dilakukan dengan pengujian dengan analisis deskriptif, analisis ini digunakan untuk menggambarkan fakta-fakta yang ada untuk selanjutnya diolah menjadi data. Data yang dianalisis diolah untuk mendapatkan sebuah kesimpulan [17]. Langkah pengujian yang dilakukan sebagai berikut.

1. Setiap indikator yang dinilai oleh responden, diklasifikasikan dalam lima alternatif jawaban dengan menggunakan skala ordinal yang menggambarkan peringkat jawaban.

2. Dihitung total skor setiap valiabel / subvariabel = jumlah skor dari seluruh indikator variabel untuk semua responden.

3. Dihitung skor setiap variabel / subvariabel $=$ rata - rata dari total skor.

4. Untuk mendeskripsikan jawaban responden, juga digunakan statistik deskriptif seperti distribusi frekuensi dan tampilan dalam bentuk tabel atau grafik

5. Untuk menjawab deskripsi tentang variabel penelitian ini, digunakan rentang kriteria penelitian sebagai berikut.

Skor Total $=\frac{\text { skor Aktual }}{\text { skor Ideal }} \times 100 \%$

Skor aktual adalah jawaban seluruh responden atas kuesioner yang telah diajukan. Skor ideal adalah skor atau bobot tertinggi atau semua responden diasumsikan memilih jawaban dengan skor tertinggi. Penjelasan bobot nilai skor aktual dapat dilihat pada tabel 1.

Tabel 1 Kriteria Tanggapan Responden

\begin{tabular}{cc}
\hline \% Jumlah Skor & Kriteria \\
\hline $\mathbf{2 0 , 0 0} \%-\mathbf{3 6 , 0 0} \%$ & Tidak Baik \\
\hline $\mathbf{3 6 , 0 1} \%-\mathbf{5 2 , 0 0} \%$ & Kurang Baik \\
\hline $\mathbf{5 2 , 0 1} \%-\mathbf{6 8 , 0 0} \%$ & Cukup \\
\hline $\mathbf{6 8 , 0 1} \%-\mathbf{8 4 , 0 0} \%$ & Baik \\
\hline $\mathbf{8 4 , 0 1} \%-\mathbf{1 0 0} \%$ & Sangat Baik \\
\hline
\end{tabular}




\section{METODE PENELITIAN}

Tahapan yang dilakukan dalam penelitian ini memiliki urutan cara kerja seperti pada gambar 4 .

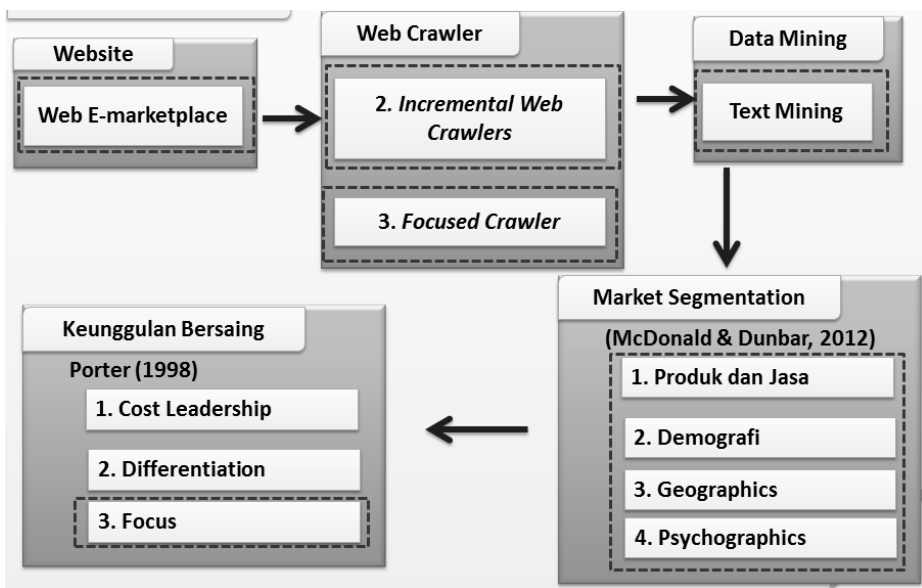

Gambar 4 Tahapan cara kerja prototipe segmentasi

Bersarjan tahapan cara kerja penelitian tentang Ekstraksi data produk e-marketplace sebagai strategi pengolahan segmentasi pasar menggunakan web crawler memiliki gambaran penelitian berupa :

1. Bukalapak.com dan Elevenia.co.id adalah situs e-marketplace untuk uji coba teknologi web crawler dalam ekstraksi data produknya.

2. Proses ekstraksi data produk dari situs Bukalapak.com dan Elevenia.co.id hanya berkaitan dengan judul produk atau nama produk, harga, toko yang menjualnya dan data-data lain untuk mendukung penyajian data segmentasi produk e-marketplace bukalapak.com.

3. Penyajian data yang dihasilkan berupa grafik berdasarkan segmentasi pasar yang diinginkan.

4. Pada penelitian ini menggunakan sebuah library simple php dom dengan melakukan modifikasi taq-taq yang di sesuai dengan keadaaan struktur html Bukalapak.com dan Elevenia.co.id.

5. Pemanfaatan penelitian ini hanya untuk digunakan pengelompokan segmentasi pasar.

\section{HASIL DAN PEMBAHASAN}

\subsection{Arsitektur Prototipe}

Aristektur dari prototipe yang dibuat adalah menggunakan library php DOM (document object model) dimana document object model adalah antarmuka platform dan bahasa netral yang akan memungkinkan program dan script untuk mengakses dan memperbarui konten, struktur dan gaya dokumen dinamis. dokumen dapat diproses lebih lanjut dan hasil pengolahan yang dapat dimasukkan kembali ke dalam halaman yang disajikan [18]. Ini adalah gambaran dari libarary DOM untuk proses crawling isi dari tag - tag html berdasarkan keyword dari pencarian yang diinputkan, proses crawling dilakukan dari situs $e$-marketplace bukalapak.com dan elevenia.co.id kemudian isi tag - tag di simpan sementara kedalam sebuah array teks yang kemudian nantinya teks -teks tersebut di kategorikan sesuai hubungan segmentasi pasar. Pada Gambar 3 memperlihatkan arsitektur prototipe yang dibuat dimana proses penginputan dilakukan oleh pengguna menggunakan pc/laptop, kemudian keyword atau kata kunci yang diinputkan di proses ke library tag -tag dengan kriteria yang peneliti inginkan.

Kriteria yang peneliti pilih yaitu kriteria produk - produk yang ada hubungannya dengan keyword dari teks yang diinputkan oleh pengguna, setelah keyword di proses oleh library DOM maka proses selanjutnya adalah mengakses tag - tag yang ada di situs e-marketplace yang hasilnya berupa isi dari tag - tag tersebut, kemudian menghasilkan teks - teks yang disimpan kedalam data sementara berupa array yang kemudian di proses untuk dilakukan pemilihan kriteria yang disimpan kedalam datastore, jika terdapat next link dari situs e-marketplace maka akan dilakukan proses sampai analisis teks - teks dari tag di situs e-marketplace selesai, setelah proses save datastore selesai kemudian akan dilakukan segmentasi berdasarkan kriteria yang dipilih oleh user. 


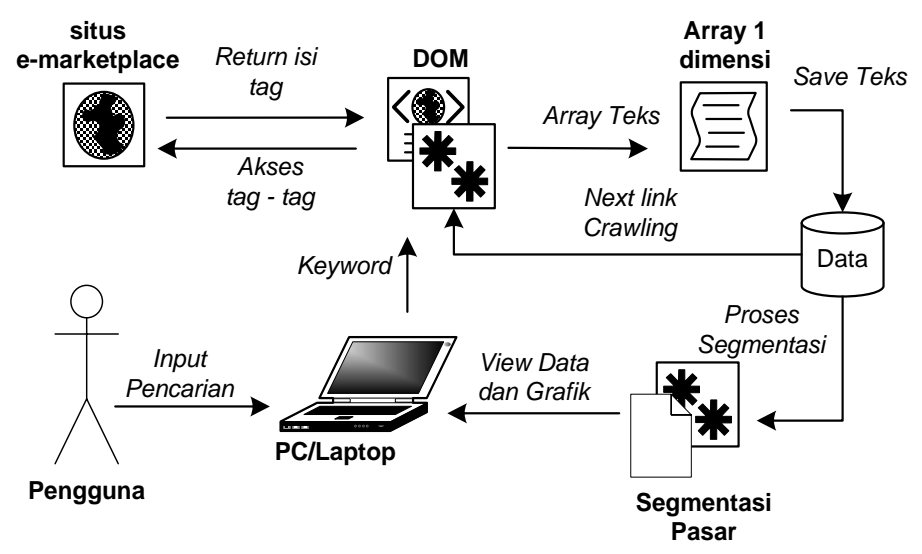

Gambar 5 Arsitektur prototipe

\subsection{Implementasi Teknologi Web Crawler}

Implementasi teknologi web crawler dimulai dengan melakukan proses modifikasi library DOM Simple PHP DOM yaitu penyesuaian tag- tag yang digunakan oleh peneliti yang disesuaikan dengan situs e-marketplace bukalapak.com dan elevenia.co.id diataranya terlihat seperti pada gambar 6 .

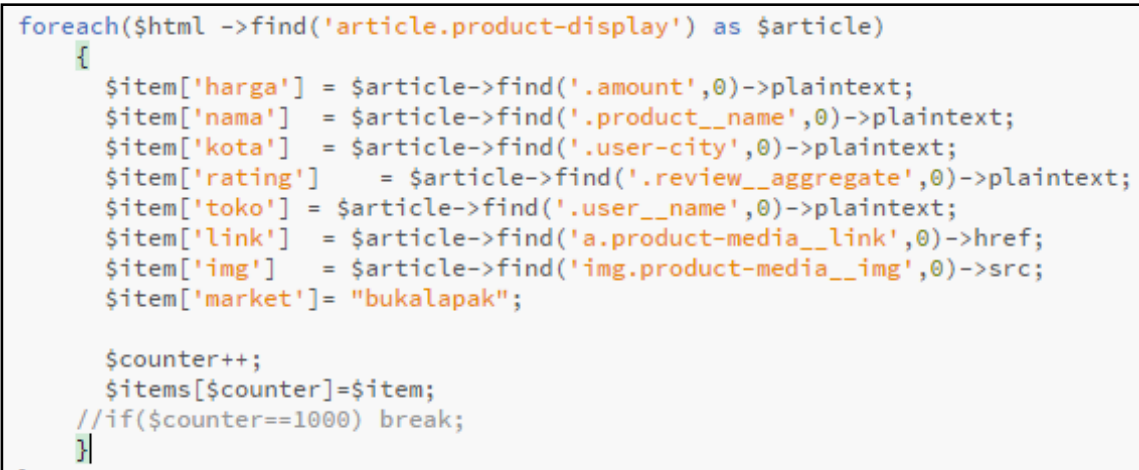

\section{Gambar 6 Modifikasi tag DOM bukalapak}

Setelah melakukan modifikasi tag pada library DOM Simple PHP DOM yaitu melakukan uji coba ekstraksi data produk e-marketplace dengan menginputkan keyword yang diinginkan pada textbox yang sudah di implementasikan dengan uji coba keyword "XIOMI" terlihat pada gambar 7.

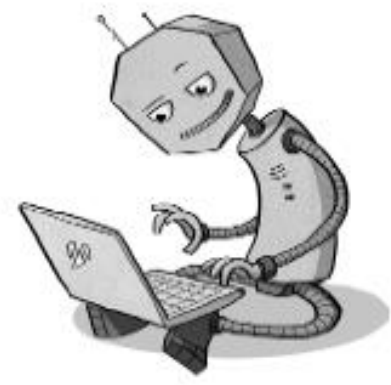

$$
\text { xiomi }
$$

\section{Gambar 7 Halaman pencarian}


Hasil dari ekstraksi data produk e-marketplace bukalapak.com dan elevenia.co.id terlihat seperti pada gambar 8 untuk dapat memilih segmentasi yang diinginkan sesuai dengan kategori Behavioral, Demografi, Geographics dan Psychographics [11].

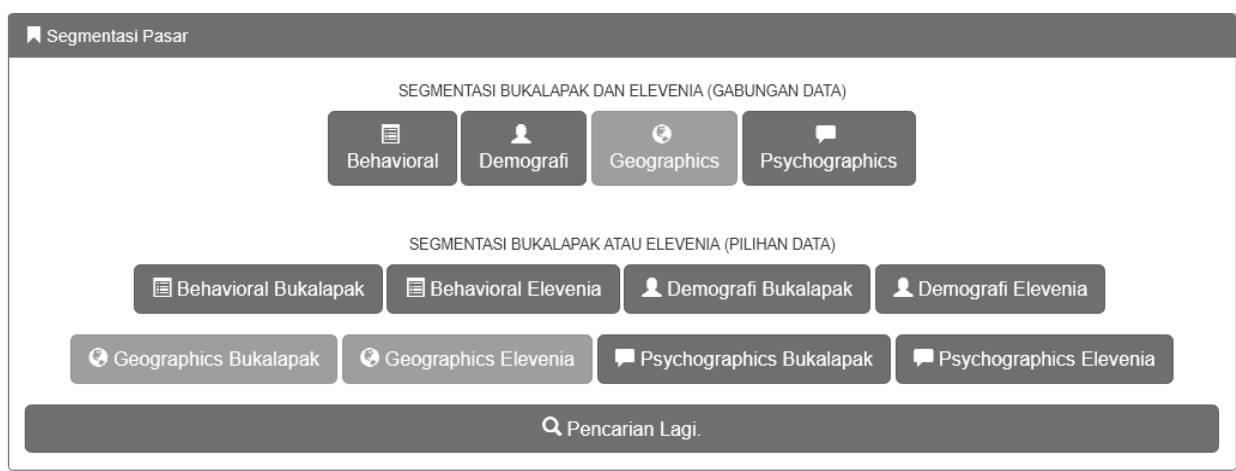

Gambar 8 Menu hasil pencarian

Kemudian hasil grafik yang dapat dilihat dari penelitian ini adalah 2 jenis grafik yaitu Pai dan Bar untuk memperlihatkan segmentasi dari Geographics ( Wilayah Penjual dan Pemilik Toko Online) seperti pada gambar 9 .

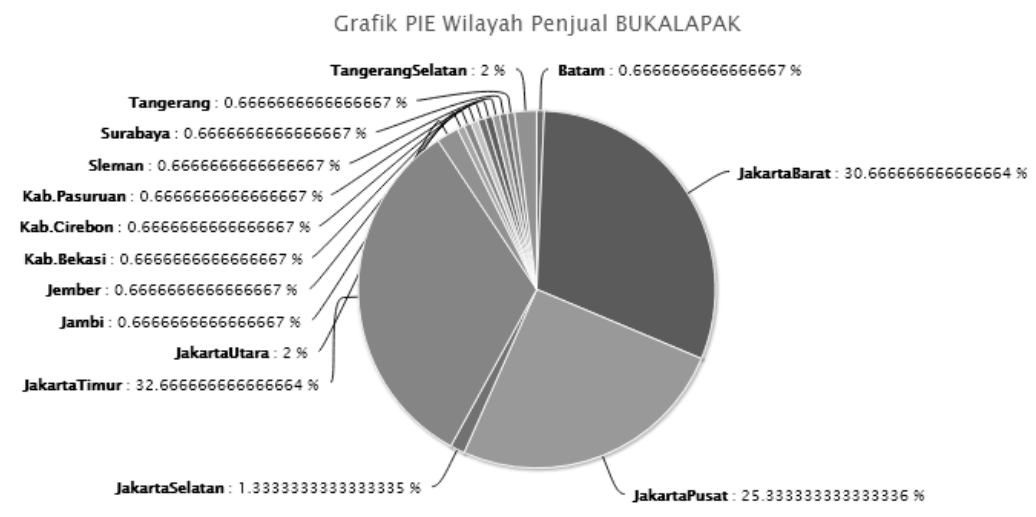

\section{Gambar 9 Menu hasil pencarian}

\subsection{Pengujian Prototipe}

Hasil pengujian diperoleh dari kuesioner dengan menggunakan 250 responden dengan karakteristik responden berdasarkan pekerjaan untuk berwirausaha atau pebisnis yang akan memulai usaha terlihat pada gambar 10.

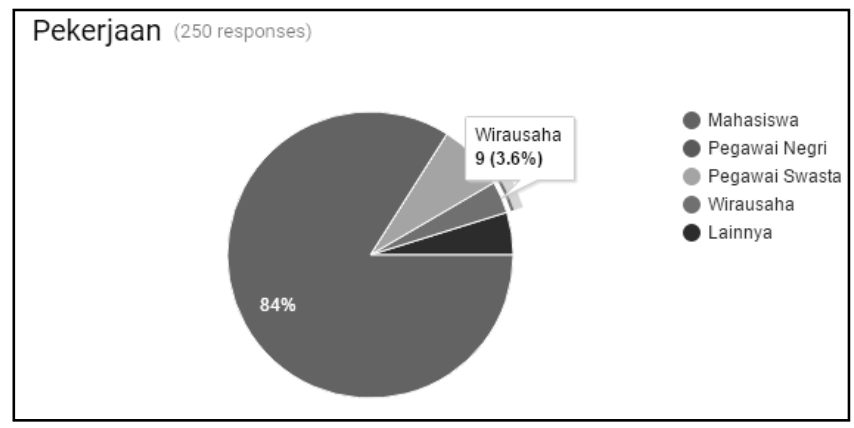

Gambar 10 Karakteristik responden 
Rekapitulasi hasil pengujian kualitas berdasarakan 5 kriteria kualitas kesuksesan sistem informasi dari prototipe terlihat pada tabel 2 .

Tabel 2 Hasil Pengujian Prototipe

\begin{tabular}{rllll}
\hline No & Kriteria & Skor Aktual & Skor Idea & \% Skor Aktual \\
\hline 1. & Kualitas Informasi & 5988 & 6250 & $80 \%$ \\
\hline 1. & Kualitas Sistem & 4961 & 6250 & $79 \%$ \\
\hline 2. & Kualitas Layanan & 2906 & 3750 & $77 \%$ \\
\hline 3. & Penggunaan & 1984 & 2500 & $79 \%$ \\
\hline 4. & Kepuasan Pengguna & 1946 & 2500 & $78 \%$ \\
\hline & Total & 16785 & 21250 & $79 \%$
\end{tabular}

Dari hasil pengolahan data tanggapan responden sebanyak 250 responden, dan berdasarkan 5 kriteria Model DeLone dan McLean maka didapat hasil dari kriteria Kualitas Informasi (Information Quality) sebesar 80 \%, Kualitas Informasi (Information Quality) sebesar 79 \%, Kualitas Layanan (Service Quality) sebesar 77 \%, Penggunaan (Use) sebesar $79 \%$, Kepuasan Pengguna (User Satisfaction) sebesar $78 \%$. Dari keseluruhan kriteria Model DeLone dan McLean untuk kesuksesan informasi segmentasi pasar sebesar $\mathbf{7 9} \%$.

Dari data diatas membuktikan bahwa penelitian ini memberikan solusi dalam upaya meningkatkan segmentasi pasar bagi pelaku bisnis dan bagi pemulai bisnis dalam berbisnis di $e$ marketplace hasilnya dikategorikan Baik sebesar $\mathbf{7 9} \%$.

\section{KESIMPULAN}

Penggunaan prototipe ini menjadi solusi yang baik untuk memulai bisnis dan pelaku bisnis untuk mengetahui segmentasi pasar di situs bukalapak.com dan elevenia.co.id untuk meletakan produk atau membuka gudang secara konvensional sesuai dengan hasil segmentasi pasar yang disajikan oleh prototipe. Hasil pengujian prototipe menggunakan Model DeLone dan McLean yang dilakukan oleh peneliti, didapat bahwa kesuksesan informasi yang disajikan dalam bentuk segmentasi pasar dengan rincian kuesioner yang disebarkan kepada 250 responden dengan 40,4\% wanita dan $59,6 \%$ pria yang dibedakan berdasarkan pekerjaan yaitu wiraswasta 9 responden, pegawai swasta 19 responden, mahasiswa 210 dan lainnya 12 responden yang mengisi kuesioner berdasarkan 5 kriteria kesuksesan sistem informasi dari Model Delone dan McLean dengan masing - masing nilai kriteria \% skor aktual yaitu : Kualitas Informasi (Information Quality) sebesar $80 \%$, Kualitas Sistem (System Quality) sebesar $79 \%$, Kualitas Layanan (Service Quality) sebesar $77 \%$, Penggunaan (Use) sebesar $79 \%$, Kepuasan Pengguna (User Satisfaction) sebesar $78 \%$ dengan kesimpulan pengujian kualitas informasi segmentasi pasar sebesar $\mathbf{7 9} \%$ dan nilai tersebut memiliki presentase tanggapan responden dalam kriteria Baik.

\section{REFERENSI}

[1] L. Sims, Building Your Online Store With WordPress and WooCommerce. 2018.

[2] “Top 50 E-Commerce Sites \& Apps in Indonesia 2018." [Online]. Available: https://iprice.co.id/insights/mapofecommerce/en/. [Accessed: 28-Aug-2019].

[3] "Digital 2019: Global Internet Use Accelerates - We Are Social." [Online]. Available: https://wearesocial.com/blog/2019/01/digital-2019-global-internet-use-accelerates. [Accessed: 28-Aug-2019].

[4] S. Dolnicar, B. Grün, and F. Leisch, "Market Segmentation Analysis," 2018, pp. 11-22.

[5] A. V. Singh and A. Mishra, "A Review of Web Crawler Algorithms," vol. 5, no. 5, pp. 66896691, 2014.

Surahman, Penulis, Judul Artikel Ekstraksi Data Produk E-Marketplace Sebagai Strategi Pengolahan Segmentasi Pasar Menggunakan Web Crawler 
[6] L. B. Ilmawan, "Membangun Web Crawler Berbasis Web Service Untuk Data Crawling Pada Website Google Play Store," Ilk. J. Ilm., vol. 10, pp. 215-224, 2018.

[7] M. Akbar, C. Patmala, and D. Nurmalasari, "Ekstraksi Data pada Tabel dari Halaman Web Menggunakan Pohon Document Object Model," J. Nas. Tek. Elektro dan Teknol. Inf., vol. 5, no. 4, pp. 2-8, 2016.

[8] E. S. Negara, R. Andryani, and H. Saksono, "Analisis Data Twitter: Ekstraksi dan Analisis Data G eospasial Twitter Data Analytics: Geospatial Data Extraction and Analysis," Inkom, vol. 10, no. 1, pp. 27-36, 2016.

[9] M. Akbar and A. Wibowo, "Ekstraksi Tabel HTML Bentuk Column-Row Wise ke dalam Basis Data," J. Teknol. Inf. dan Ilmu Komput., vol. 5, no. 6, p. 653, 2018.

[10] A. Sasongko, "Dan Teknologi Komputer Integrasi Data Website Students . Bsi . Ac . Id Untuk Mobile Infokampus Berbasis Android Menggunakan,” Sasongko Agung, vol. 2, no. 2, pp. 146155, 2017.

[11] M. McDonald and I. Dunbar, Market Segmentation:How to do it and how to profit from it, vol. 111, no. 479. United Kingdom: John Wiley \& Sons Ltd, 2012.

[12] W. H. DELONE and E. R. MCLEAN, "The DeLone and McLean Model of Information Systems Success: A Ten-Year Update,” J. Manag. Inf. Syst., vol. 19, no. 4, pp. 9-30, 2003.

[13] T. McGill, V. Hobbs, and J. Klobas, "User-developed applications and information systems success: A test of DeLone and McLean's model," Inf. Resour. Manag. J., vol. 16, no. 1, pp. 24-45, 2003.

[14] P. H. Saputro, D. Budiyanto, and J. Santoso, "Model Delone and Mclean Untuk Mengukur Kesuksesan E-Government Kota Pekalongan," Sci. J. Informatics, vol. 2, no. 1, pp. 1-8, 2016.

[15] J. W. Lian, "Establishing a cloud computing success model for hospitals in Taiwan," Inq. (United States), vol. 54, 2017.

[16] I. Nofikasari and A. Sunyoto, "Evaluasi Penerapan Sistem Informasi Akademik Dengan Pendekatan Model Delone \& McLean, HOT FIT dan UTAUT (Studi Kasus: STMIK Duta Bangsa Surakarta)," J. Tek. Inform., vol. 12, no. April, pp. 81-90, 2017.

[17] U. Narimawati, Riset Manajemen Sumber Daya Manusia. Jakarta: Agung Media, 2007.

[18] J. Keith, DOM Scripting : Web Design with javascript and the documen objecy model, vol. 53, no. 9. United States of America: Paul Manning, 2010. 